\title{
The effect of various light conditions and different nitrogen forms on nitrogen metabolism in pepper fruits
}

\author{
Anna Kotton*, Renata Wojciechowska, Maria Leja \\ Department of Botany and Plant Physiology \\ University of Agriculture in Krakow \\ 29 Listopada 54, 31-425 Kraków, Poland
}

\begin{abstract}
The 'Spartacus' $F_{1}$ sweet pepper was grown in a plastic tunnel on rockwool during 2006-2008. A fertigation technique was used for water and fertiliser application. The tunnel was divided into two parts covered with different plastic films. The first part of the tunnel was covered with a film that transmitted less light than the film covering the second part. In both parts of the tunnel, the plants were divided into two groups. One group of plants was fertilised with just nitrate nitrogen $\left(100 \% \mathrm{~N}-\mathrm{NO}_{3}\right)$ and the other one with three forms of nitrogen $\left(\mathrm{N}-\mathrm{NO}_{3}: \mathrm{N}-\mathrm{NH}_{4}: \mathrm{N}_{-} \mathrm{NH}_{2}\right.$ in a ratio of 50:13:37). Fruits were harvested mature green and red. Concentrations of nitrate and ammonium ions as well as total nitrogen and free amino acids were analysed in the plant material. Nitrate and nitrite reductase activities were also investigated, and dry matter content and soluble sugars were also determined. Higher light intensity increased nitrate concentration in red pepper fruits but decreased ammonium ion content. These tendencies were not as obvious in green fruits. In most cases, red fruits fertilised with three nitrogen forms accumulated more nitrates than those fertilised with $\mathrm{N}_{-} \mathrm{NO}_{3}$. This observation was similar in the case of green fruits. In most cases, pepper fruits accumulated more ammonium ions in the case of $\mathrm{N}-\mathrm{NO}_{3}$ fertilisation than when three forms of nitrogen were applied, but the differences were not always statistically significant. Higher nitrate reductase activity was observed in the case of better light conditions as well as mixed nitrogen fertilisation in red pepper fruits. No differences were observed in the case of nitrite reductase activity between fruits harvested from various treatments in red and also green fruits, with some exceptions. The green fruits of pepper had higher nitrate reductase activity than the red ones. It can be summarised that various light conditions influenced the nitrogen metabolism of pepper fruits as well as the different nitrogen forms applied with fertilisers.
\end{abstract}

Key words: ammonium, nitrates, nitrate/nitrite reductase, pepper, radiation

\section{INTRODUCTION}

Sweet pepper is becoming more and more popular in Poland, and because of its chemical composition it is very beneficial for the human diet both as a fresh and processed vegetable. Pepper fruits are rich in vitamins, minerals, carotenoids and phenols (Wien 1997, Wall et al. 2001, Kołton et al. 2011). There is plenty of information about the effects of growing and storage conditions on the health promoting compounds in pepper fruits. But there is a lack of information about fruit nitrogen metabolism influenced by selected environmental factors.

Plant nitrogen metabolism might be considered as nitrogen acquisition, reduction, transport, storage 
and incorporation into organic compounds. Nitrogen is taken up mainly by the roots as nitrate or ammonium ions as well as its organic form (urea). These forms of nitrogen can be changed and transported to fruits or transferred without changing forms. Nitrogen in fruits can be accumulated as ions (nitrate, nitrite or ammonium) or organic compounds (like amino acids); however, it may also change during fruit development and maturation.

The main steps of nitrogen metabolism are the accumulation of ions, reduction of nitrates and introduction of ammonium ions in amino acids. All of these processes are influenced by many factors such as nitrate, nitrite and ammonium ion concentration in cells, amino acid and sugar accumulation or environmental factors - mainly light conditions (Campbell 1999, Glass et al. 2002, Stitt et al. 2002, Lillo 2004).

The aim of the presented study was to evaluate the effect of various light conditions and fertilisation with different nitrogen forms on some aspects of nitrogen metabolism in sweet pepper fruits grown in a plastic tunnel on rockwool.

\section{MATERIAL AND METHODS}

The 'Spartacus' $F_{1}$ sweet pepper was grown in 20062008 in a high plastic tunnel located at the Faculty of Horticulture of the University of Agriculture in Krakow in three growing cycles. The tunnel had a dimension of $50 \times 9 \mathrm{~m}$. Every year, 774 plants were cultivated during the experiment in 12 gutters. The tunnel was covered with a double layer of plastic film and divided into two parts. The first part of the tunnel (A) was covered with a film that transmitted less light than the film covering the second part (B). Analysis of both plastic films was done using a LiCor Li1800 spectroradiometer when the films were clean and at the end of experiment. At the beginning, film A transmitted nearly $10 \%$ less light in the range of 400-700 $\mathrm{nm}$ than film B (Tab. 1). What is interesting is that the biggest difference in transmitted radiation between both films was in the range of $400-500 \mathrm{~nm}$. At the end of the experiment, the differences were smaller because of dust and other pollution. An analysis of the radiation inside and outside of the tunnel on a sunny day with a LiCor Li1800 spectroradiometer was also done in 2008 (Fig.1).

In both parts of the tunnel, under both plastic films, the plants were divided into two groups: the first one was fertilised with only nitrate nitrogen $\left(100 \% \mathrm{~N}-\mathrm{NO}_{3}\right)$ and the second one with three forms

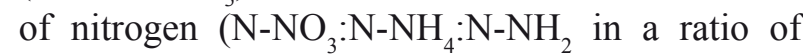
50:13:37). Mineral nutrients were introduced in the concentration recommended for pepper cultivation in a solution (in $\mathrm{mg} \mathrm{dm}^{-3}: \mathrm{N}=150-155, \mathrm{P}=55$ $65, \mathrm{~K}=180-210, \mathrm{Ca}=145-185, \mathrm{Mg}=30-35, \mathrm{pH}=$ $5.0-5.8, \mathrm{EC}=1.9-2.3)$. The nutrient solutions also contained microelements in $\mathrm{mg} \mathrm{dm}^{-3}: \mathrm{Fe}=2, \mathrm{Mn}=$ 0.4-0.55, B = 0.27-0.40, $\mathrm{Zn}=0.32, \mathrm{Cu}=0.04-0.07$, $\mathrm{Mo}=0.05$.

Because of various light conditions and different forms of nitrogen, four treatments were applied in the presented experiment:

1. tunnel A (covered with film transmitting less light), $\mathrm{N}-\mathrm{NO}_{3}$ fertilisation, 189 plants

2. tunnel $\mathrm{A}, \mathrm{N}-\mathrm{NO}_{3} / \mathrm{N}-\mathrm{NH}_{4} / \mathrm{N}-\mathrm{NH}_{2}$ fertilisation, 189 plants

3. tunnel $\mathrm{B}, \mathrm{N}-\mathrm{NO}_{3}$ fertilisation, 198 plants

4. tunnel $\mathrm{B}, \mathrm{N}-\mathrm{NO}_{3} / \mathrm{N}-\mathrm{NH}_{4} / \mathrm{N}-\mathrm{NH}_{2}$ fertilisation, 198 plants.

The fruits of sweet pepper of the $4^{\text {th }}$ internode were harvested at two maturity stages: mature green and red. At each maturity stage, 30 fruits per treatment were harvested (10 from each gutter). The blended fruit material (only the flesh) was used for chemical analysis. The concentration of nitrate and ammonium ions were detected using an Orion $920 \mathrm{~A}+$ ionometer. Total nitrogen was estimated using the Kjeldahl method. Free amino acids were analysed using a ninhydrine reagent method (Yemm et al. 1955, Sun et al. 2006, Wang 2012). For the determination of dry matter, plant material was dried at $105^{\circ} \mathrm{C}$. Nitrate (NR) and nitrite (NiR) reductase activities were measured using the Buczek method $(1976,1984)$. Soluble sugars were

Table 1. Light transmission through plastic materials covering tunnel

\begin{tabular}{lccccc}
\hline \multicolumn{2}{l}{ Material covering tunnel } & \multicolumn{5}{c}{ Light transmission (\%) } \\
\hline Type & Age & $400-700 \mathrm{~nm}$ & $400-500 \mathrm{~nm}$ & $500-600 \mathrm{~nm}$ & $600-700 \mathrm{~nm}$ \\
\hline A & \multirow{2}{*}{ new } & 63.7 & 59.5 & 64.5 & 67.3 \\
B & & 73.1 & 72.4 & 73.0 & 73.9 \\
A & 57.1 & 51.7 & 57.9 & 61.9 \\
B & used & 60.1 & 55.4 & 60.8 & 64.1 \\
\hline
\end{tabular}




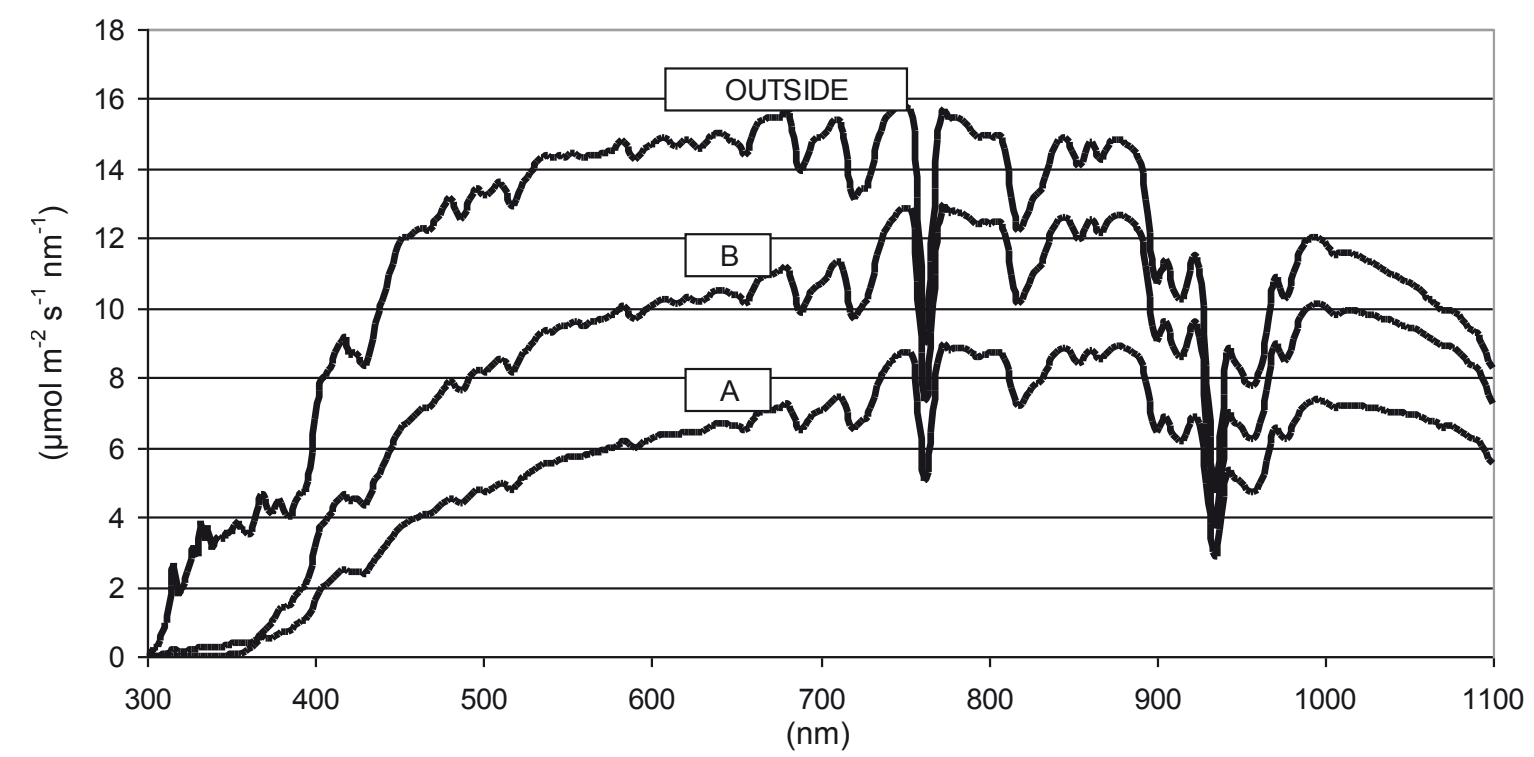

Figure 1. Spectral irradiance in an open area (outside of tunnel) and transmittance of radiation through plastic material covering tunnel: A and B (inside)

determined using an anthrone reagent method (Yemm and Wills 1954).

All analyses were made in three replications. The results were statistically evaluated using ANOVA and the Fisher LSD test for the significance $p=0.05$. Homogenous groups are represented by the same letters. Pearson's correlation coefficient was calculated for selected parameters for the significance $\mathrm{p}=0.05$.

\section{RESULTS}

Green pepper fruits accumulated similar amounts of nitrate ions independent of either light conditions or nitrogen fertilisation (three year averages). Considering each year separately, mixed fertilisation (with three forms of nitrogen) increased the accumulation of nitrates in green fruits. This was also observed in the case of red fruits (Tab. 2).

Light conditions had no effect on nitrate accumulation in green fruits; however, in the case of red fruits, higher light intensity increased nitrate concentration. An effect of nitrogen forms on ammonium ion concentration in green pepper fruits was observed only in 2007, but the effect of mixed nitrogen forms was opposite on that parameter in both light conditions. In the case of red fruits treated with the mixed nitrogen form, an increased concentration of ammonium ions was observed only when fruits were harvested from the tunnel covered with plastic transmitting less light. A higher intensity of light decreased concentration of ammonium ions.
It is interesting that the mean nitrate reductase activity in green pepper fruits was independent of experimental factors, but in the case of red fruits, better light conditions induced activity of this enzyme especially in the case of mixed nitrogen fertilisation. In plants grown in the tunnel covered with plastic transmitting less light, mixed nitrogen fertilisation increased nitrate reductase activity in green fruits only in 2007. In the case of green fruits fertilised with $\mathrm{N}-\mathrm{NO}_{3}$, better light conditions increased activity of that enzyme in 2007. In 2006, only better light conditions increased nitrate reductase activity in red fruits. The same effect of light on that enzyme in red fruits was observed in 2007 and 2008 in the case of plants fertilised with $\mathrm{N}-\mathrm{NO}_{3}$. An increase of nitrate reductase activity as an effect of mixed nitrogen fertilisation was observed in 2007 in the case of red fruits harvested from better light conditions and in 2008 in the case of red fruits harvested from the tunnel covered with plastic transmitting less light. The activity of nitrite reductase was higher than nitrate reductase and independent of testing conditions in both types of fruits. During 2007, a higher light intensity decreased the accumulation of total nitrogen in green pepper fruits; however, this was not as evident in 2008 (Tab. 3). An opposite observation was recorded in 2007 in the case of red fruits: better light conditions caused higher nitrogen accumulation. The concentration of free amino acids in green and red fruits did not depend on the tested conditions (three year averages). 


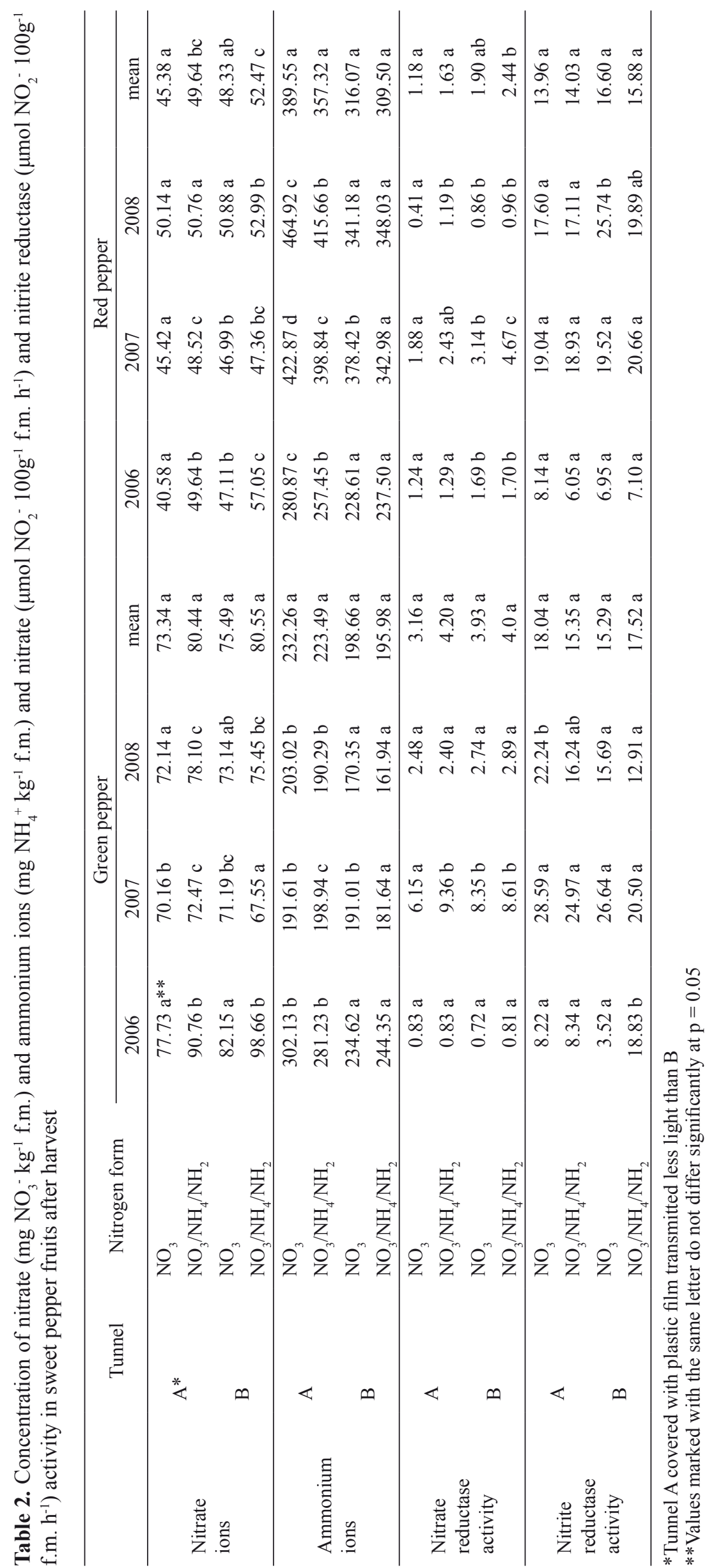




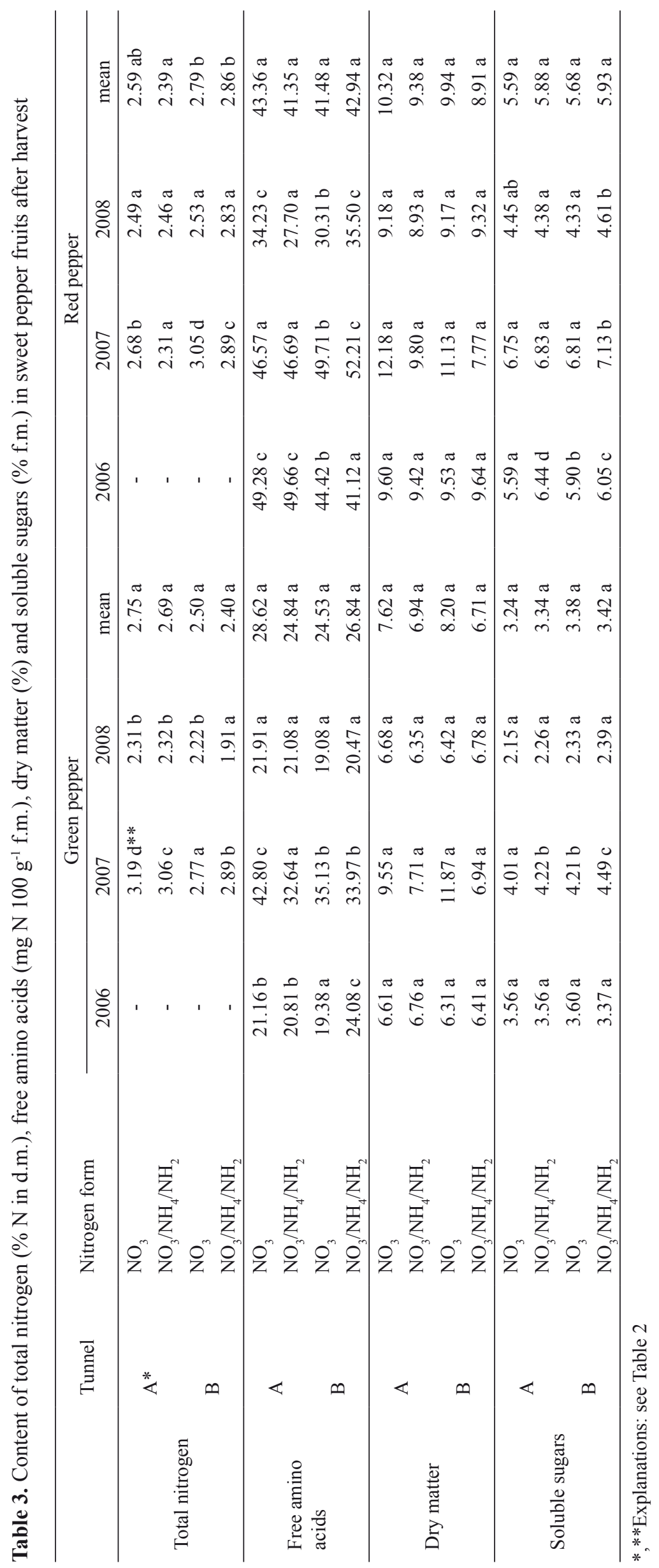


There was no influence of the investigated factors on dry matter content in green and red pepper fruits (Tab. 3). Soluble sugar concentration did not depend on light and fertilisation in green fruits except in 2007. Green fruits obtained from plants fertilised with three forms of nitrogen and grown under higher radiation accumulated more sugars in 2007. The same tendency was also observed in the case of red fruits.

In the case of green fruits, a significant correlation was found between the average concentration of nitrates and ammonium ions ( $\mathrm{r}$ $=0.61$ ), activities of nitrate and nitrite reductase $(r=0.64)$, concentration of soluble sugars and free amino acids $(r=0.69)$ as well as free amino acids and dry matter content $(r=0.61)$. In the case of red fruits, the only significant correlation was found between the average concentration of soluble sugars and free amino acids $(r=0.90)$.

\section{DISCUSSION}

As a generative organ, the edible part of pepper fruit does not accumulate large amounts of nitrate (Santamaria 2006, Majkowska-Gadomska et al. 2009). In the presented study, the concentration of nitrate in pepper fruits was on the low level acceptable in a human diet. In previous studies, some researchers observed an effect of nitrogen fertiliser form on nitrate accumulation in plants (Santamaria 2006). In the present work, pepper fruits collected from plants fertilised with three forms of nitrogen accumulated more nitrates in comparison to those

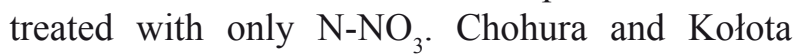
(2011) found a lower concentration of nitrates in radish roots when ammonium nitrogen was used as related to nitrate nitrogen application. In the present study, the application of three nitrogen forms decreased or increased the concentration of ammonium ions in pepper fruits. So the results obtained in the present paper are controversial and difficult to be explained.

The nitrogen form in fertilisers may affect the activity of nitrate reductase in plants (Wojciechowska 2002). Ammonium addition may enhance the activity of nitrate reductase as compared to nitrate only fertilisation (Leleu and Vuylsteker 2004). The reduced form of nitrogen in plant feeding could stabilise the activity of that enzyme. However, the influence of nitrogen form on nitrate reductase was not observed in pepper fruits. Similarly, the effect of tested nitrogen form on nitrite reductase activity in pepper fruits was not noted. According to Lea (1997), nitrate ions may stimulate both of these enzymes and, because they were present in both nutrient solutions, no effect of nitrogen fertilisation was found.

Total nitrogen concentration in pepper fruits was similar in the case of both nitrogen treatments. Bar-Tal et al. (2001) observed that nitrogen content in pepper fruit was independent of its form used in fertilisation, similarly as in the presented study.

The concentration of free amino acids, dry matter and soluble sugars in pepper fruits was also unaffected by nitrogen form. This fact may show that both kinds of nitrogen feeding could be useful in the case of sweet pepper cultivation, although some authors observed a toxic influence of ammonium ions on that plant (Schnitzler et al. 2004). An increase of dry matter content in pepper fruit as an effect of reduced nitrogen forms in fertilisation was observed by Bar-Tal et al. (2001).

Green pepper fruits accumulated similar amounts of nitrate ions during cultivation in both tested light conditions. However, the stimulation of nitrate accumulation was observed in the case of red pepper fruits harvested from plants radiated with light of a higher intensity. Different results were reported by Caruso et al. (2004), who observed a reduction of nitrates in pepper at better light conditions. According to Prieto et al. (2007), higher light intensity could stimulate the accumulation of nitrogen in pepper. Lower ammonium content in pepper fruits in the case of higher radiation was also observed in the presented experiment.

Better light conditions increased nitrate reductase activity in red pepper fruits. Many researchers have reported the positive effect of light on nitrate reductase activity in plants (Neyra 1986, Marschner 1995, Kaiser et al. 1999, Lillo 2004). Light conditions did not affect dry matter content in pepper fruits in our investigation. An ambiguous effect of light on free amino acid content and nitrogen concentration was observed in this study. Higher radiation increased the concentration of soluble sugars in pepper fruits but differences were not significant in every case. Wyżgolik et al. (2008) observed a higher net photosynthesis of pepper plants grown in better light conditions. This may explain sugar accumulation in fruits grown in higher radiation. A high positive correlation between radiation and dry matter content in pepper fruits was observed by Prieto et al. (2007). In addition, a high light intensity increased sugar concentration in pepper (Caruso et al. 2004). It can be summarised that various light conditions influenced nitrogen metabolism of 
pepper fruits as well as different nitrogen forms applied with fertilisers.

\section{CONCLUSIONS}

1. Higher light intensity increased nitrate ion concentration and nitrate reductase activity in red pepper fruits.

2. Three forms of nitrogen nutrients $\left(\mathrm{N}-\mathrm{NO}_{3} / \mathrm{N}-\right.$ $\mathrm{NH}_{4} / \mathrm{N}-\mathrm{NH}_{2}$ ) increased nitrate content and also decreased ammonium accumulation in red fruits.

3. Nitrate ion accumulation was higher in the case of mixed nitrogen fertilisation in green fruits.

4. The effect of the tested conditions on nitrogen metabolism of pepper fruits was dependent on the maturation stage.

\section{ACKNOWLEDGEMENTS}

The study was financed by the State Committee for Scientific Research in Poland, under project No. 2P06R 021 30. This work was supported under "InnoGrant - the innovation activities of postgraduate students supporting programme". Special thanks to prof. dr hab. Jan Pilarski for his support with the spectroradiometer.

\section{REFERENCES}

Bar-Tal A., Aloni B., Karni L., Rosenberg R., 2001. Nitrogen nutrition of greenhouse pepper. II. Effect of nitrogen concentration and $\mathrm{NO}_{3}: \mathrm{NH}_{4}$ ratio on growth, transpiration, and nutrient uptake. HortScience 36(7): 1252-1259.

BuczeK J., 1976. The role of light in the induction of nitrate and nitrite reductase in cucumber seedlings. Acta Soc. Bot. Pol. 45: 77-92.

BuczeK J., 1984. The occurrence of nitrate reductase inactivating factor in extracts of Spirodela polyrrhiza. Acta Soc. Bot. Pol. 53: 411-417.

Campbell W.H., 1999. Nitrate reductase structure, function and regulation: bridging the gap between biochemistry and physiology. Ann. Rev. Plant Physiol. Plant Mol. Biol. 50: 277-303.

Caruso G., Villari A., Impembo M., 2004. Effect of nutritive solution EC and shading on berry chemical composition of NFT-grown 'Friariello' pepper. Acta Hort. 659: 783-790.

Сhohura P., Коцота E., 2011. The effect of nitrogen fertilisation on radish yielding. Acta Sci. Pol. Hortorum Cultus 10(1): 23-30.

Glass A.D.M., Britto D.T., Kaiser B.N., Kinghorn J.R., Kronzucker H.J., Kumar A., OKamoto M., Rawat S., Siddiqi M.Y., Unkles S.E., Vidmar J.J., 2002. The regulation of nitrate and ammonium transport systems in plants. J. Exp. Bot. 53(370): 855-864.
Kaiser W.M., Weiner H., Huber S.C., 1999. Nitrate reductase in higher plants: a case study for transduction of environmental stimuli into control of catalytic activity. Physiol. Plant. 105: 385-390.

KoŁton A., Wojciechowska R., Leja M., 2011. Effect of maturity stage and short-term storage on the biological quality of sweet pepper fruits. Veg. Crop Res. Bul. 74: 143-152.

LEA P.J., 1997. The regulation of nitrate assimilation. In: Plant biochemistry. P.M. Dey and J.B. Harborne (eds), Academic Press, UK: 284.

Leleu O., Vuylsteker C., 2004. Unusual regulatory nitrate reductase activity in cotyledons of Brassica napus seedlings: enhancement of nitrate reductase activity by ammonium supply. J. Exp. Bot. 55(398): 815-823.

Lillo C., 2004. Light regulation of nitrate uptake, assimilation and metabolism. In: Nitrogen acquisition and assimilation in higher plants. S. Amâncio and I. Stulen (eds), Kluwer Academic Publisher, Dordrecht: 149-184.

MajkowsKa-GadomsKa J., ARCichowsKa K., WierzBicKa B., 2009. Nitrate content of the edible parts of vegetables and spice plants. Acta Sci. Pol., Hortorum Cultus 8(3): 25-35.

MARSCHNER H., 1995. Mineral nutrition of higher plants. Academic Press.

Neyra C.A., 1986. Nitrate reductase: biochemistry and regulation. In: Biochemical Basis of Plant Breeding. CRC Press, Inc.

Prieto M., Peñalosa J., Sarro M.J., Zornoza P., Gárate A., 2007. Seasonal effect on growth parameters and macronutrient use of sweet pepper. J. Plant Nutr. 30: 1803-1820.

Santamaria P., 2006. Nitrate in vegetables: toxicity, content, intake and EC regulation (review). J. Sci. Food Agric. 86: 10-17.

Schnitzler W.H., Sharma A.K., Gruda N.S., Heuberger H.T., 2004. A low-tech hydroponic system for bell pepper (Capsicum annuum L.) production. Acta Hort. 644: 47-53.

Stitt M., Müller C., Matt P., Gibon Y., Carillo P., Morcuende R., Scheible W.R., Krapp A., 2002. Steps towards as integrated view of nitrogen metabolism. J. Exp. Bot. 53(370): 959-970.

Sun S.W., Lin Y.C., Weng Y.M., Chen M.J., 2006. Efficiency improvements on ninhydrin method for amino acid quantification. J. Food Comp. Anal. 19: 112-117.

Wall M.M., Waddell C.A., Bosland P.W., 2001. Variation in $\beta$-carotene and total carotenoid content in fruits of Capsicum. HortScience 36(4): 746-749.

WANG N.S., 2012. Amino acid assay by ninhydrin colorimetric method. Available online at http://www. eng.umd.edu/ nsw/ench485/lab3a.htm; cited on 17 Oct 2012.

WIEN H.C., 1997. The physiology of vegetable crops. CAB International. 
WojciechowsKa R., 2002. The nitrate and nitrite reductase activity in cabbage (Brassica oleraces var. capitata) as related to nitrate content modified by different nitrogen fertilisation. Veg. Crop Res. Bul. 56: 31-38.

Wyżgolik G., Nawara J., Leja M., 2008. Photosynthesis and some growth parameters of sweet pepper grown under different light conditions. Sodininkyste ir Daržininkyste 27(2): 93-98.

Yemm E.W., Cocking E.C., Ricketts R.E., 1955. The determination of amino-acids with ninhydrin. Analyst 80: 209-214.

Yemm E.W., WiLls A.J., 1954. The estimation of carbohydrates in plant extracts by anthrone. Biochem. J. 58: 508-514.

\section{WPŁYW ZRÓŻNICOWANYCH WARUNKÓW ŚWIETLNYCH I FORMY AZOTU NAWOZOWEGO NA METABOLIZM AZOTU W OWOCACH PAPRYKI}

Streszczenie: Paprykę słodką 'Spartacus' $F_{1}$ uprawiano w latach 2006-2008 w tunelu foliowym na wełnie mineralnej $\mathrm{z}$ wykorzystaniem systemu do fertygacji roślin. Tunel był podzielony na dwie części: jedna część była pokryta folią przepuszczającą mniej światła niż druga część. W obu częściach tunelu rośliny podzielono na dwie grupy nawożone różnymi formami azotu. Jedna grupa dostawała azot wyłącznie w formie $\mathrm{N}-\mathrm{NO}_{3}$, a druga grupa dostawała mieszaninę trzech form azotu $\left(\mathrm{N}-\mathrm{NO}_{3}: \mathrm{N}-\mathrm{NH}_{4}: \mathrm{N}-\mathrm{NH}_{2}\right.$ w stosunku 50:13:37). W doświadczeniu wydzielono zatem cztery obiekty zróżnicowane pod względem warunków świetlnych i formy azotu nawozowego.
Z roślin zbierano owoce dojrzałe zielone i czerwone. W owocach oznaczono zawartość jonów azotanowych i amonowych oraz azotu ogółem, aktywność reduktazy azotanowej i azotynowej, zawartość suchej masy, wolnych aminokwasów i cukrów rozpuszczalnych. Lepsze warunki świetlne wpłynęły na podniesienie zawartości azotanów w owocach czerwonych papryki choć zależność ta nie zawsze była statystycznie istotna. Takiej zależności nie wykazano w przypadku owoców zielonych. W większości przypadków czerwone owoce papryki pod wpływem nawożenia trzema formami azotu akumulowały więcej azotanów niż podczas traktowania roślin wyłącznie $\mathrm{N}-\mathrm{NO}_{3}$. Podobne obserwacje zanotowano w przypadku owoców zielonych. Średnia zawartość jonów amonowych w owocach zielonych i czerwonych nie była zależna od badanych czynników doświadczenia. Czerwone owoce zebrane $\mathrm{z}$ roślin rosnących $\mathrm{w}$ lepszych warunkach świetlnych charakteryzowały się wyższą średnią aktywnością reduktazy azotanowej. Średnia aktywność tego enzymu w owocach zielonych była na podobnym poziomie w każdym z czterech obiektów doświadczenia. Aktywność reduktazy azotynowej była na podobnym poziomie we wszystkich badanych obiektach. Dodatkowo zielone owoce charakteryzowały się wyższą aktywnością reduktazy azotanowej niż owoce czerwone. Podsumowując stwierdzono, że zarówno warunki świetlne, jak i forma azotu nawozowego modyfikowały metabolizm azotowy owoców papryki.

Received August 23, 2012; accepted November 16, 2012 